\title{
Bioremediation and Detoxification of Synthetic Wastewater Containing Triarylmethane Dyes by Aeromonas hydrophila Isolated from Industrial Effluent
}

\author{
Chimezie Jason Ogugbue ${ }^{1,2}$ and Thomas Sawidis ${ }^{1}$ \\ ${ }^{1}$ School of Biology, Aristotle University of Thessaloniki, Thessaloniki 54124, Macedonia, Greece \\ ${ }^{2}$ Department of Microbiology, University of Port Harcourt, Port Harcourt 500004, Nigeria
}

Correspondence should be addressed to Chimezie Jason Ogugbue, ceejay55us@yahoo.com

Received 3 February 2011; Revised 23 May 2011; Accepted 24 May 2011

Academic Editor: Yu Hong Wei

Copyright (C) 2011 C. J. Ogugbue and T. Sawidis. This is an open access article distributed under the Creative Commons Attribution License, which permits unrestricted use, distribution, and reproduction in any medium, provided the original work is properly cited.

\begin{abstract}
Economical and bio-friendly approaches are needed to remediate dye-contaminated wastewater from various industries. In this study, a novel bacterial strain capable of decolorizing triarylmethane dyes was isolated from a textile wastewater treatment plant in Greece. The bacterial isolate was identified as Aeromonas hydrophila and was shown to decolorize three triarylmethane dyes tested within $24 \mathrm{~h}$ with color removal in the range of $72 \%$ to $96 \%$. Decolorization efficiency of the bacterium was a function of operational parameters (aeration, dye concentration, temperature, and $\mathrm{pH}$ ) and the optimal operational conditions obtained for decolorization of the dyes were: $\mathrm{pH} 7-8,35^{\circ} \mathrm{C}$ and culture agitation. Effective color removal within $24 \mathrm{~h}$ was obtained at a maximum dye concentration of $50 \mathrm{mg} / \mathrm{L}$. Dye decolorization was monitored using a scanning UV/visible spectrophotometer which indicated that decolorization was due to the degradation of dyes into non-colored intermediates. Phytotoxicity studies carried out using Triticum aestivum, Hordeum vulgare, and Lens esculenta revealed the triarylmethane dyes exerted toxic effects on plant growth parameters monitored. However, significant reduction in toxicity was obtained with the decolorized dye metabolites thus, indicating the detoxification of the dyes following degradation by Aeromonas hydrophila.
\end{abstract}

\section{Introduction}

Worldwide, dye wastewater has become one of the main sources of severe pollution problems due to the greater demand for textile products and the proportional increase in production and applications of synthetic dyes [1]. It is estimated that over 10,000 different dyes and pigments are used industrially and over 0.7 million tons of synthetic dyes are produced annually worldwide [2]. In the textile industry, up to 200,000 tons of these dyes are lost to effluents every year during dyeing and finishing operations as a result of inefficiency in the dyeing process [3, 4]. Unfortunately, most of these dyes escape conventional wastewater treatment processes and persist in the environment as a result of their high stability against light, temperature, water, detergents, chemicals, and microbial attack [5]. Notwithstanding, industries are required to eliminate color from their effluents containing dyes, before disposal into water bodies, due to environmental legislation [6].

Among the many different groups of synthetic dyes, triarylmethane (also called triphenylmethane) dyes are one of the most commonly used in the textile industries. Their usage constitutes about $30 \%-40 \%$ of the total consumption of dyes [7], and they are applied extensively on nylon, cotton, wool, and silk. They are also used for coloring food, oils, fats, waxes, varnishes, cosmetics, paper, leather, and plastics [8] as well as for staining specimens in bacteriological and histopathological processes. With dye tinctorial value usually high, less than $1 \mathrm{ppm}$ of dye in water produces obvious coloration [9], and the extensive use of these dyes have resulted in highly colored effluents that may affect gas solubility in water bodies [10] and significantly decrease photosynthetic activity in aquatic life because of reduced light penetration. In addition to their visual effect, 
triarylmethane dyes are generally believed to be toxic and carcinogenic or prepared from other known carcinogens $[11,12]$. Several reports have also shown that textile dyes and effluents have toxic effects on plants which perform important ecological functions such as providing a habitat for wildlife, protecting soil from erosion, and providing the organic matter that is so significant to soil fertility [13]. Consequently, it is pertinent to develop efficient treatment strategies for removal of color from dye wastewater.

Various physicochemical methods, such as adsorption on activated carbon, electrocoagulation, flocculation, froth flotation, ion exchange, membrane filtration, ozonation, and reverse osmosis have been used for decolorization of dyes in wastewater $[2,14]$. However, these methods are less efficient, costly, of limited applicability, and produce wastes, which are difficult to dispose of [15]. On the contrary, biological processes provide a low-cost, environmentally benign, and efficient alternative for the treatment of dye wastewater [16].

Decolorization by biological means may take place in two ways: either by adsorption (or biosorption) on the microbial biomass or biodegradation by the cells [17]. Biosorption involves the entrapment of dyes in the matrix of the adsorbent (microbial biomass) without destruction of the pollutant, whereas in biodegradation, the original dye structure is fragmented into smaller compounds resulting in the decolorization of synthetic dyes. Several researchers have described the use of microorganisms as biosorption agents in the removal of pollutants from wastewater [1820]. However, due to operational ease and facile adaptability of microorganisms to a given set of conditions, the biodegradation mechanism is considered efficacious in comparison to biosorption for treatment of dye wastewater [21]. Over the past few decades, numerous microorganisms have been isolated and characterized for degradation of various synthetic dyes, but most of the reports have dealt mainly with decolorization of azo dyes [22-24]. There is a dearth of information regarding the degradation and detoxification of triarylmethane dyes by microbial systems despite their increased use by the textile industry. Hence, the isolation of potent species that have the capability for degradation and detoxification of triarylmethane dyes is of interest in the biotechnological aspect of dye effluent treatment.

In this study, a bacterial strain, Aeromonas hydrophila, capable of decolorizing triarylmethane dyes was isolated from textile industrial wastewater using the selective enrichment method. The effects of various parameters (such as culture agitation, initial dye concentration, $\mathrm{pH}$, and temperature) on dye decolorization by the bacterial strain were investigated and the toxicity of the products formed after decolorization was determined using plant assay.

\section{Materials and Methods}

2.1. Chemicals. The triarylmethane dyes (Basic violet 14 , Basic violet 3, and Acid blue 90) used in this study were purchased from Sigma Chemical Co. (St. Louis, Mo, USA). The chemical structures and characteristics of the dyes used are depicted in Table 1. The stock solutions of each dye were prepared by membrane filtration. All other chemicals used were of analytical grade.

2.2. Bacteria and Growth Medium. The bacterial strain used was isolated from dye wastewater obtained from Textile of Thessaloniki, SA, Greece. The principle of sequential selective enrichment batch culture for selection of dye decolorizing bacteria was employed in synthetic wastewater medium (SWM) with Basic Violet 3 as the carbon source. The basic composition of the synthetic wastewater medium was $(\mathrm{g} / \mathrm{L}) ;\left(\mathrm{NH}_{4}\right)_{2} \mathrm{SO}_{4} 0.28, \mathrm{NH}_{4} \mathrm{Cl} 0.23, \mathrm{KH}_{2} \mathrm{PO}_{4}$ 0.067, $\mathrm{MgSO}_{4} \cdot 7 \mathrm{H}_{2} \mathrm{O} 0.04, \mathrm{CaCl}_{2} \cdot 2 \mathrm{H}_{2} \mathrm{O} 0.022, \mathrm{FeCl}_{3} \cdot 6 \mathrm{H}_{2} \mathrm{O} 0.005$, $\mathrm{NaCl} 0.15, \mathrm{NaHCO}_{3} 1.0$, and $1 \mathrm{~mL} / \mathrm{L}$ of a trace element solution containing $(\mathrm{g} / \mathrm{L}) ; \mathrm{ZnSO}_{4} \cdot 7 \mathrm{H}_{2} \mathrm{O} 0.01, \mathrm{MnCl}_{2} \cdot 4 \mathrm{H}_{2} \mathrm{O} 0.1$, $\mathrm{CuSO}_{4} \cdot 5 \mathrm{H}_{2} \mathrm{O} 0.392, \mathrm{CoCl}_{2} \cdot 6 \mathrm{H}_{2} \mathrm{O} 0.248, \mathrm{NaB}_{4} \mathrm{O}_{7} \cdot 10 \mathrm{H}_{2} \mathrm{O}$ 0.177 , and $\mathrm{NiCl}_{2} \cdot 6 \mathrm{H}_{2} \mathrm{O} 0.02$. The textile wastewater used for isolation of dye-decolorizing bacteria was acclimatized for 8 weeks prior to transfer into $250 \mathrm{~mL}$ Erlenmeyer flasks containing $100 \mathrm{~mL}$ SWM. After incubation of the flasks, a mixed culture that showed quick and stable decolorization activity was transferred to newly prepared SWM. After five successive transfers, it was plated on SWM agar containing $20 \mathrm{mg} / \mathrm{L}$ of each dye and incubated at $30^{\circ} \mathrm{C}$ for 5 days. Bacterial colonies around which clear zones expanded quickly were picked for further studies and designated as TTW 1-5. To check for the dye-degrading potential of each bacterial isolate, preliminary batch experiments were carried out using sterile $250 \mathrm{~mL}$ Erlenmeyer flasks containing $100 \mathrm{~mL}$ of SWM spiked with dye, after which the solution was inoculated with freshly grown bacterial cells. The final $\mathrm{pH}$ was 7.2. The bacterial isolate that showed the highest ability to degrade the triarylmethane dyes was selected and used for subsequent investigations. The selected bacterium (TTW 4) was characterized and identified as Aeromonas hydrophila using Gram stain, spore test, motility test, and a battery of biochemical and physiological tests (Table 2) as described by Vanderzannt and Splittstoesser [25] and Cheesbrough [26] and with reference to the Bergey's Manual of Determinative Bacteriology [27].

2.3. Batch Decolorization Operation. The decolorization of the triarylmethane dyes was studied in $250 \mathrm{~mL}$ Erlenmeyer flasks containing $100 \mathrm{~mL}$ of SWM and bacterial biomass in a batch mode. Each flask was inoculated with $2 \mathrm{~mL}$ of freshly grown Aeromonas hydrophila. The inoculum size was adjusted at optical density 1.0 at $\lambda=620 \mathrm{~nm}(1.50 \times$ $10^{7}$ cells $/ \mathrm{mL}$ ) and incubated under shaking $(150 \mathrm{rpm})$ and static conditions at $30^{\circ} \mathrm{C}$. To evaluate the effects of other operational factors on the efficiency of color removal, the batch decolorization experiments were carried out at different initial dye concentrations $(1-100 \mathrm{mg} / \mathrm{L})$, temperatures $\left(15^{\circ} \mathrm{C}-45^{\circ} \mathrm{C}\right)$ and initial $\mathrm{pH}(4-10)$ under shaking incubation condition. Thereafter, optimal conditions of $35^{\circ} \mathrm{C}$ and $\mathrm{pH} 7$ and initial dye concentration of $50 \mathrm{mg} / \mathrm{L}$ were used in subsequent experiments under shaking condition. Three types of control were used: uninoculated sterile control, heat-killed control, and sodium azide $(0.1 \% \mathrm{w} / \mathrm{v})$ amended 
TABLE 1: Chemical structures and characteristics of triarylmethane dyes used in this study.

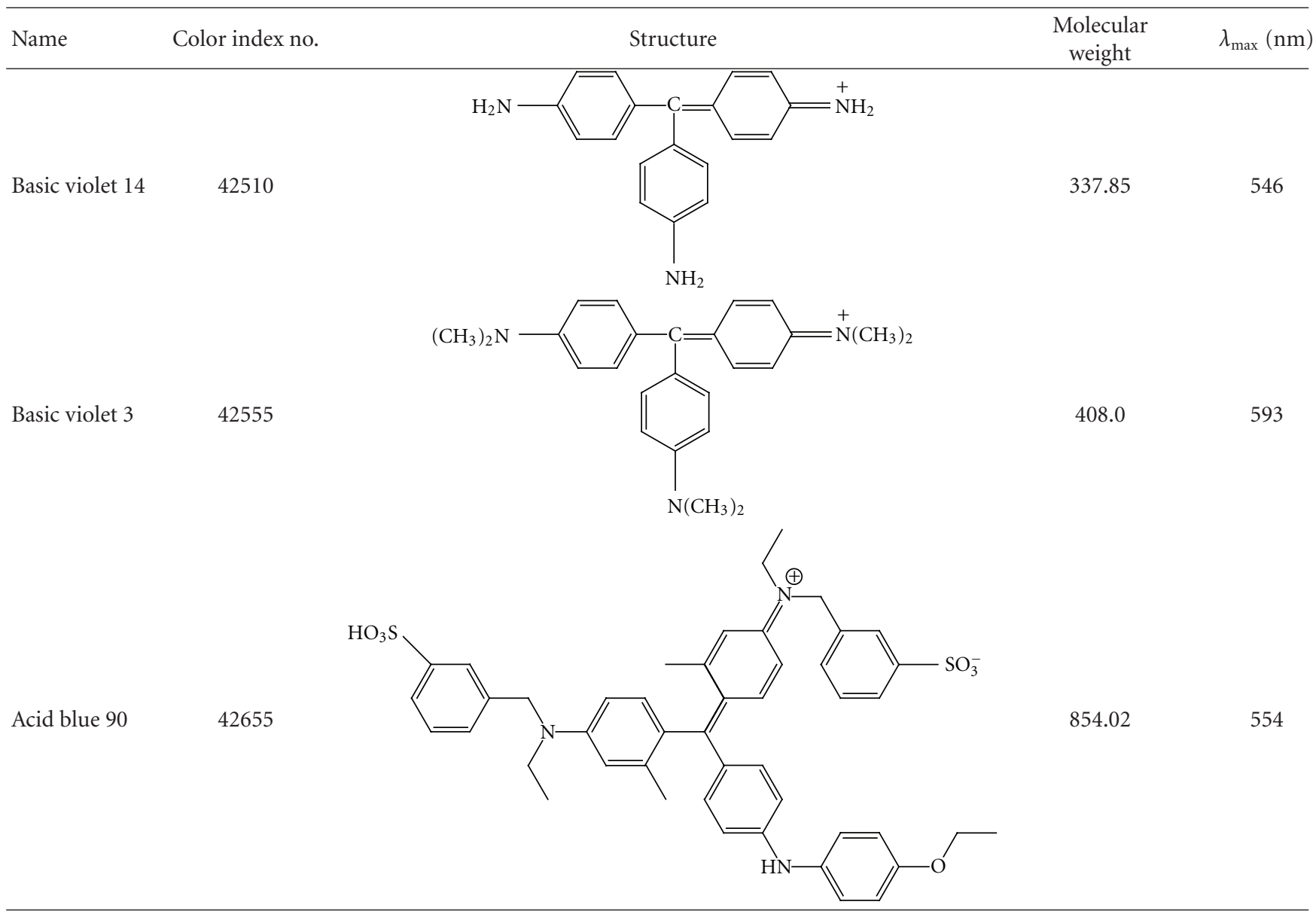

control. The first indicated the effect of medium components on decolorization, and the latter two showed adsorption of dyes on cells. After incubation, aliquots $(5 \mathrm{~mL})$ were taken and centrifuged at $10,000 \mathrm{rpm}$ for $15 \mathrm{~min}$ to separate the bacterial cell mass and obtain a clear supernatant, which was used to measure the absorbance of culture samples at the maximum absorption wavelength $\left(\lambda_{\max }\right)$ of the respective dyes using a scanning spectrophotometer (Shimadzu UV2401 PC model Kyoto, Japan). Residual dye concentration of samples was then obtained from a calibration curve of dye concentration versus absorbance prepared for each dye. Decolorization activity was determined by using adsorption $(A)$ and dye removal by living biomass $(R)$ which were calculated according to the following formulae [28]:

$$
\begin{aligned}
& A(\%)=\left[\frac{C_{0}-C_{1}}{C_{0}}\right] \times 100 \%, \\
& R(\%)=\left[\frac{C_{0}-C_{1 L}}{C_{0}}\right] \times 100 \%,
\end{aligned}
$$

where $C_{0}$-the concentration $(\mathrm{mg} / \mathrm{L})$ of dye in control sample, $C_{1}$-the residual concentration $(\mathrm{mg} / \mathrm{L})$ of dye in culture samples with killed or sodium azide treated cells, $C_{1 L}-$ the residual concentration $(\mathrm{mg} / \mathrm{L})$ of dye in samples with living biomass. Enumeration of bacterial counts in culture flasks was carried out on plate count agar (Merck) after 10 -fold serial dilution of culture samples using the spreadplate method. Viable cell counts obtained after incubation for $24 \mathrm{~h}$ at $35^{\circ} \mathrm{C}$ were expressed as colony-forming units per $\mathrm{mL}(\mathrm{CFU} / \mathrm{mL})$.

2.4. Toxicity Study. Phytotoxicity studies were carried out with $50 \mathrm{mg} / \mathrm{L}$ of each dye and its extracted metabolites using seeds of Triticum aestivum, Hordeum vulgare and Lens esculenta with SWM as control. The degradation metabolites of each dye extracted in ethyl acetate were dried and dissolved in water to form the final concentration of $50 \mathrm{mg} / \mathrm{L}$ for phytotoxicity studies [12]. The seeds were surface sterilized with $1.2 \%$ sodium hypochloride solution to discourage fungal growth. Fifteen seeds of each plant species were placed in each Petri dish in sets and watered separately with $5 \mathrm{~mL}$ samples of each dye and its degradation product per day. The Petri dishes were kept in the dark and observed for germination. Seeds with radicle $(>1 \mathrm{~mm})$ were considered germinated [29]. The germinated seeds were then exposed to day and night cycle length of $10 / 14 \mathrm{~h}$, respectively, with a temperature regime of about $28 \pm 2^{\circ} \mathrm{C}$. The length of plumule (shoot) and radicle (root), and the germination rate (\%) were recorded after 7 days. 
TABLE 2: Morphological, physiological, and biochemical characteristics of isolate TTW 4.

\begin{tabular}{|c|c|}
\hline Test & Aeromonas hydrophila \\
\hline \multicolumn{2}{|l|}{ Cellular morphology } \\
\hline Shape & Bacilli \\
\hline Gram reaction & Gram negative \\
\hline Motility & Motile \\
\hline Presence of endospore & - \\
\hline \multicolumn{2}{|l|}{ Physiological tests } \\
\hline Growth at $25-43^{\circ} \mathrm{C}$ & + \\
\hline Growth at $\mathrm{pH} 4-10$ & + \\
\hline Salt tolerance & $4 \%$ \\
\hline \multicolumn{2}{|l|}{ Biochemical tests } \\
\hline Catalase & + \\
\hline Oxidase & + \\
\hline Indole & + \\
\hline Methy red & - \\
\hline Voges proskauer & + \\
\hline Citrate utilization & + \\
\hline \multicolumn{2}{|l|}{ Hydrolysis of: } \\
\hline Arbutin & + \\
\hline Esculin & + \\
\hline Gelatine & + \\
\hline Starch & + \\
\hline Urea & - \\
\hline$\beta$-haemolysis & + \\
\hline DNAse & + \\
\hline Gas from glucose & + \\
\hline Hydrogen sulphide production & + \\
\hline $\mathrm{KCN}$ & + \\
\hline Lipase & + \\
\hline ONPG & + \\
\hline LDC & + \\
\hline $\mathrm{ADH}$ & + \\
\hline ODC & - \\
\hline PPA & + \\
\hline Tyrosine & - \\
\hline \multicolumn{2}{|l|}{ Acid from } \\
\hline Adonitol & - \\
\hline Galactose & + \\
\hline L-Arabinose & + \\
\hline Cellobiose & - \\
\hline Glycerol & + \\
\hline$m$-Inositol & - \\
\hline Lactose & - \\
\hline Maltose & + \\
\hline Mannose & + \\
\hline D-Mannitol & + \\
\hline Melibiose & - \\
\hline Trehalose & + \\
\hline Raffinose & - \\
\hline
\end{tabular}

TABLE 2: Continued.

\begin{tabular}{cc}
\hline Test & Aeromonas hydrophila \\
\hline Xylose & - \\
Salicin & + \\
D-Sorbitol & - \\
Sucrose & + \\
\hline
\end{tabular}

Abbreviations: ONPG, o-nitrophenyl: D-galactopyranoside; VP, VogesProskauer; LDC, lysine decarboxylase; ODC, ornithine decarboxylase; ADH, arginine dihydrolase; PPA, phenylpyruvic acid (phenylalanine deaminase).

2.5. Statistical Analysis. Data presented are means of three replicates $( \pm \mathrm{SE})$ obtained from three independent experiments. Data were analyzed using analysis of variance (ANOVA), with the Dunett post hoc test to check for interactive effects between factors [30]. The significance level was set at $5 \%$.

\section{Results and Discussion}

3.1. Isolation of Dye-Degrading Bacteria. Five bacterial isolates that exhibited dye decolorization potentials on SWM agar spiked with Basic violet 3 were picked and screened for their ability to degrade three triarylmethane dyes (Basic violet 14, Basic violet 3 and Acid blue 90). The bacterial isolates decolorized the three dyes albeit to varying degrees (Table 3) within $24 \mathrm{~h}$, and further decolorization of the dyes by the isolates was obtained after $36 \mathrm{~h}$. The variation in decolorization efficiency of the isolates may be attributed to differences in the chemical structure of the dyes [10] and the varying metabolic functions of the different bacterial isolates. Decolorization of the dyes by the isolates was found to be due to degradation to a greater extent than adsorption as $\%$ adsorption obtained were quite low compared to \% dye reduction by viable cells. Isolate TTW 4 did not show any evidence of adsorption after $24 \mathrm{~h}$. Adsorption and/or degradation are the two mechanisms responsible for dye decolorization by microorganisms. Dye adsorption may be evident from inspection of the bacterial growth as those adsorbing dyes will be deeply colored, whereas those causing degradation will remain colorless. While the isolate TTW 4 cells cultured for $8 \mathrm{~h}$ with the dyes were colored, none of the cells was colored with any one of the dyes tested after incubation and decolorization for $24 \mathrm{~h}$. Decolorization assay of a butanol extract of the cell pellets after incubation for $24 \mathrm{~h}$ with the dyes showed that the dyes were not adsorbed to the cell (data not shown). This indicates that decolorization of the dyes was mainly due to degradation rather than adsorption to cells. The deeply colored cell mats after $8 \mathrm{~h}$ may be explained by the fact that adsorption is frequently the first step of the biodegradation process before transportation of dye into the cytoplasm and its eventual breakdown by viable microbial cells. However, adsorption levels most times are an indication of biotransformation efficiency or its absence as rapid dye biodegraders rarely show high adsorption rates upon decolorization and incubation for an extended time period. In another experiment carried out using viable, autoclaved (killed), and metabolically 
TABLE 3: Color removal efficiency of dye-degrading bacteria isolated from industrial wastewater.

\begin{tabular}{|c|c|c|c|c|c|c|}
\hline \multirow[t]{2}{*}{ Isolate } & \multicolumn{2}{|c|}{ Basic violet 14} & \multicolumn{2}{|c|}{ Basic violet 3} & \multicolumn{2}{|c|}{ Acid blue 90} \\
\hline & $\begin{array}{l}\text { Decolorization } \\
\text { due to reduction } \\
(\%)\end{array}$ & $\begin{array}{l}\text { Decolorization } \\
\text { due to } \\
\text { adsorption (\%) }\end{array}$ & $\begin{array}{c}\text { Decolorization } \\
\text { due to reduction } \\
(\%)\end{array}$ & $\begin{array}{l}\text { Decolorization } \\
\text { due to } \\
\text { adsorption (\%) }\end{array}$ & $\begin{array}{c}\text { Decolorization } \\
\text { due to reduction } \\
(\%)\end{array}$ & $\begin{array}{l}\text { Decolorization } \\
\text { due to } \\
\text { adsorption (\%) }\end{array}$ \\
\hline TTW 1 & $74.0 \pm 0.5$ & $2.5 \pm 0.8$ & $45.0 \pm 0.8$ & $6.8 \pm 0.8$ & $30.2 \pm 0.5$ & $6.2 \pm 0.2$ \\
\hline TTW 2 & $52.2 \pm 0.8$ & $6.0 \pm 1.2$ & $40.5 \pm 0.2$ & $6.4 \pm 1.4$ & $35.0 \pm 0.9$ & $5.8 \pm 0.8$ \\
\hline TTW 3 & $65.5 \pm 0.3$ & $3.5 \pm 0.6$ & $52.0 \pm 1.4$ & $7.6 \pm 0.8$ & $33.8 \pm 0.7$ & $3.5 \pm 0.7$ \\
\hline TTW 4 & $90.4 \pm 0.5$ & ND & $78.6 \pm 0.5$ & $0.8 \pm 0.2$ & $82.6 \pm 0.5$ & ND \\
\hline TTW 5 & $48.8 \pm 0.7$ & $5.8 \pm 0.7$ & $34.7 \pm 0.6$ & $7.8 \pm 0.5$ & $25.0 \pm 0.3$ & $7.3 \pm 0.3$ \\
\hline
\end{tabular}

Values are means of triplicate determinations. ND—not detected.

TABLE 4: Color removal efficiency of viable and nonviable Aeromonas hydrophila cells.

\begin{tabular}{|c|c|c|c|c|}
\hline \multirow[b]{2}{*}{ Dye used } & \multicolumn{4}{|c|}{$\%$ Dye decolorization } \\
\hline & $\begin{array}{c}\text { Control } \\
\text { (uninoculated) }\end{array}$ & $\begin{array}{l}\text { Inoculated I } \\
\text { (Killed cells) }\end{array}$ & $\begin{array}{c}\text { Inoculated II } \\
\text { (sodium azide treated) }\end{array}$ & $\begin{array}{c}\text { Inoculated III } \\
\text { (viable cells) }\end{array}$ \\
\hline Basic violet 14 & ND & $3.1 \pm 0.25$ & $2.5 \pm 0.15$ & $78 \pm 2.5$ \\
\hline Basic violet 3 & ND & $3.4 \pm 0.18$ & $3.5 \pm 0.28$ & $70 \pm 2.0$ \\
\hline Acid blue 90 & ND & $4.5 \pm 0.40$ & $4.0 \pm 0.37$ & $54 \pm 3.0$ \\
\hline
\end{tabular}

Values are means of triplicate determinations. ND—not detected.

poisoned cells of isolate TTW 4, dye decolorization was below $4.5 \%$ for the killed and poisoned cells while the viable cells exhibited color removal ranging from $54 \%-78 \%$ (Table 4). Hence, color removal exhibited by viable cells was attributed to the biotransformation of these dyes by the metabolic functions of the bacterium. Prior to now, various authors $[31,32]$ had reported the isolation of a gene $(t m r)$ encoding the enzyme, triphenylmethane reductase $(\mathrm{TpmD})$, from bacteria, and we believe that this enzyme may be responsible for the bioconversion of the dyes tested. The visual change in biomass color of the killed and poisoned cells and their resuspension in methanol showed that the slight decolorization of their culture medium observed was due to adsorption of dyes on bacterial cells. Decolorization (adsorption) by dead cells may be due to the increase of the cell wall area that ruptured during autoclaving and may also be attributed to the revealing of special sites on cell walls [33]. Based on results, isolate TTW 4 which was identified as Aeromonas hydrophila was selected as having the best dye decolorization potential, since it showed little or no sorption of the three dyes and exhibited rapid decolorization of dyes within $24 \mathrm{~h}$. TTW 4 was, thus, considered a good candidate for effective biological treatment of textile wastewater and used for further studies.

3.2. Effect of Agitation on Decolorization. The isolate, A. hydrophila, exhibited effective color removal activity only when incubated under shaking condition, whereas poor decolorization $(<30 \%)$ for the three dyes was obtained under static condition (Figure 1). Under agitated condition, decolorization percentages of dyes were $90 \%, 75 \%$, and $66 \%$ for Basic violet 14, Basic violet 3, and Acid blue 90, respectively, within $24 \mathrm{~h}$ of incubation. Incubation under agitated condition was also necessary for better cell growth in contrast

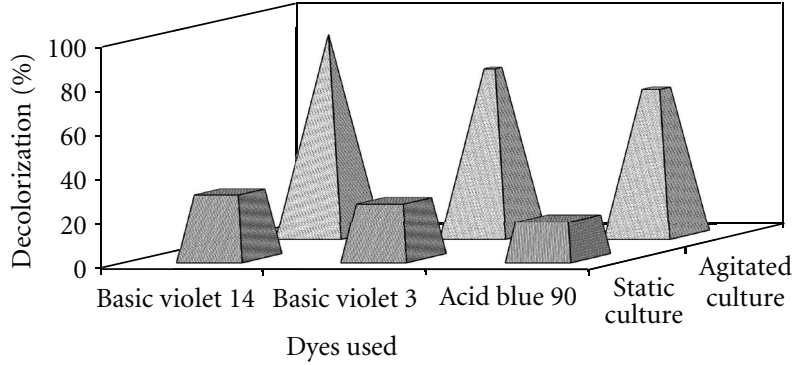

Figure 1: Decolorization of synthetic dye wastewater containing triarylmethane dyes under agitated and static conditions by Aeromonas hydrophila $\left(\mathrm{pH} 7 ; 30^{\circ} \mathrm{C} ; 24 \mathrm{~h}\right)$. Values are means of triplicate determinations

to incubation under static condition (data not shown). Poor decolorization of the dyes obtained under static condition could be attributed to the limitation of oxygen needed for the oxidative breakdown of the triarylmethane moiety, since enhanced decolorization was obtained when static cultures were subsequently incubated under agitated condition. A. hydrophila also exhibited maximum decolorization of dyes when $0.02 \%(\mathrm{w} / \mathrm{v})$ yeast extract, starch or other carbon sources were supplemented in the medium (data not shown). In absence of a cosubstrate, the bacterial culture showed reduced decolorization rates which suggested that the availability of a supplementary carbon source probably for generation of NADH molecules seems to be necessary for growth and decolorization of dyes. A previous report [34] had shown that both NADH/NADPH and molecular oxygen are necessary for the enzyme TpmD to decolorize triphenylmethane dyes which indicated that the enzyme is an NADH/NADPH-dependent oxygenase. Textile industrial 


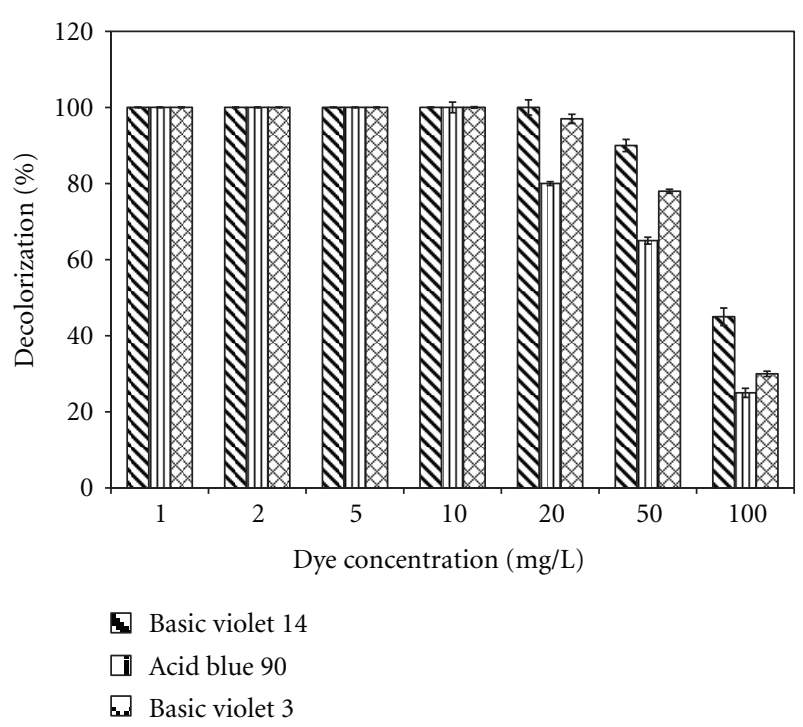

Figure 2: Decolorization of synthetic dye wastewater at different initial concentrations of triarylmethane dyes by Aeromonas hydrophila $\left(\mathrm{pH} 7 ; 30^{\circ} \mathrm{C} ; 24 \mathrm{~h}\right)$. Values are means of triplicate determinations. Error bars represent standard deviations.

wastewaters usually contain sizing agents such as starch, polyvinyl alcohol (PVA) and carboxymethyl cellulose added during sizing to provide strength to the fibers and minimize breakage [1], and these substances may serve as cosubstrates for bacteria during effluent treatment for the generation of NADH molecules.

\subsection{Effect of Initial Dye Concentration on Decolorization.}

The decolorization of dyes was studied at various increasing initial concentrations of each dye $(1-100 \mathrm{mg} / \mathrm{L})$. Results obtained show complete decolorization of dyes at initial concentrations between 1 and $20 \mathrm{mg} / \mathrm{L}$ within $24 \mathrm{~h}$ (Figure 2). However, decrease in \% decolorization with increase in dye concentration was obtained at concentrations above $20 \mathrm{mg} / \mathrm{L}$. Decolorization percentages of 90,78 , and 65 were obtained for Basic violet 14, Basic violet 3, and Acid blue 90 , respectively, at $50 \mathrm{mg} / \mathrm{L}$ initial dye concentration, and this indicates that an acceptable high color removal can be achieved with A. hydrophila in culture broths with dye concentrations below $50 \mathrm{mg} / \mathrm{L}$. For industrial applications, it is important to know whether the microorganisms that decolorize dyes can bear high concentrations of the compound since the dye concentration in a typical industrial effluent can vary between 10 and $50 \mathrm{mg} / \mathrm{L}$ [35]. A. hydrophila could decolorize the dyes at concentrations higher than those reported in waste waters and thus, it can be successfully exploited for treatment of dye bearing industrial waste waters. Zablocka-Godlewska et al. [28] had reported that Chryseomonas luteola (42\% removal) and Pseudomonas aeruginosa (40.5\% removal) had the ability to decolorize $50 \mathrm{mg} / \mathrm{L}$ concentration of triphenylmethane dyes within 7 days. In comparison, our test isolate A. hydrophila showed $65 \%-90 \%$ decolorization of $50 \mathrm{mg} / \mathrm{L}$ of the triarylmethane dyes tested within $24 \mathrm{~h}$ (Figure 2). These results show that

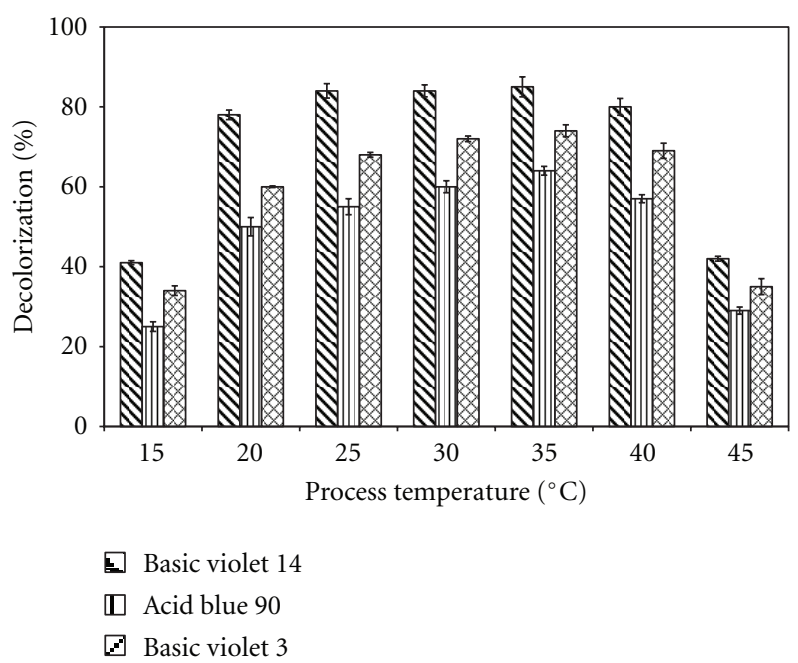

FIGURE 3: Decolorization of synthetic dye wastewater containing triarylmethane dyes at different incubation temperatures by Aeromonas hydrophila (agitated culture; pH 7; 24h). Values are means of triplicate determinations. Error bars represent standard deviations.

A. hydrophila has a higher decolorization potential compared to the other bacteria reported previously. Decreased \% decolorization of dyes obtained at higher concentrations suggests increasing dye toxicity with increase in dosage. Toxic effect was probably due to inhibition of cellular metabolic activities and cell growth. Several authors have also reported decreasing color removal with increasing dye concentration during decolorization of other dyes by bacteria $[22,36,37]$.

3.4. Effects of Temperature and $p H$. In the experiments carried out at different temperatures, the initial dye concentration and $\mathrm{pH}$ were fixed at $50 \mathrm{mg} / \mathrm{L}$ and 7 respectively, and the temperature effect was investigated at the range of $15^{\circ} \mathrm{C}-45^{\circ} \mathrm{C}$. Results show that the temperature effect on decolorization was significant over the examined range (Figure 3 ) as dye decolorization increased as the temperature was elevated to $40^{\circ} \mathrm{C}$. On further incubation, the same $\%$ dye decolorization was eventually reached in all flasks incubated at different temperatures suggesting the test isolate could acclimatize to a broad range of temperatures $\left(15^{\circ} \mathrm{C}-40^{\circ} \mathrm{C}\right)$. The optimal temperature for bacterial activity was $35^{\circ} \mathrm{C}$ (Figure 3 ) and further increase in temperature beyond that resulted in marginal reduction in dye decolorization but essentially, thermal deactivation of decolorization activity under operational temperatures did not occur. Decline in bacterial activity at higher temperatures $\left(>45^{\circ} \mathrm{C}\right)$ may be attributed to loss of cell viability or denaturation of the catabolic enzyme [37, 38]. Determination of temperature requirements of microorganisms used for biotechnological applications is paramount, since temperature requirements above-ambient ranges may require an energy input and hence not cost effective.

Effect of initial $\mathrm{pH}$ on the biodegradation efficiency of the isolate was analyzed over a $\mathrm{pH}$ range of 4 to 11 (Figure 4). 


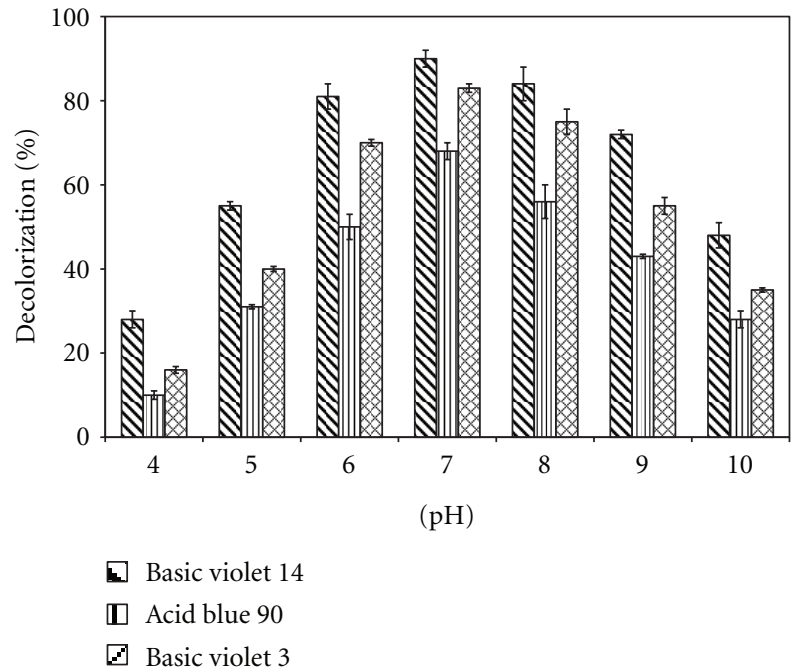

Figure 4: Decolorization of synthetic dye wastewater containing triarylmethane dyes at different initial $\mathrm{pH}$ by Aeromonas hydrophila (agitated culture; $35^{\circ} \mathrm{C} ; 24 \mathrm{~h}$ ). Values are means of triplicate determinations. Error bars represent standard deviations.

To confirm if $\mathrm{pH}$ had any effect on decolorization of the dyes at the $\mathrm{pH}$ range studied, the absorbance signature of each dye was monitored at the different $\mathrm{pH}$ and no change in the visible spectra was obtained at this $\mathrm{pH}$ range. The degree of color removal observed varied with $\mathrm{pH}$ as increase in $\mathrm{pH}$ from 4 to 7 led to a threefold increase in $\%$ decolorization. Differences in biodegradation efficiency were insignificant between $\mathrm{pH} 7$ and 9. Below $\mathrm{pH} 4$ and above $\mathrm{pH} 10$, negligible decolorization by this bacterium was observed. Though neutral $\mathrm{pH}$ (7) was best for degradation of the dyes, $\mathrm{pH} 9$ appeared to be well tolerated and significant amount of dye could be degraded at that $\mathrm{pH}$, thus indicating the potential of this organism to degrade dyes over a range of $\mathrm{pH}$. Tolerance to varying $\mathrm{pH}$ by dye-decolorizing bacteria is quite important, as it makes them suitable for practical biotreatment of dyeing mill effluents [39, 40]. However, to achieve the best rate of degradation, it is suggested that the $\mathrm{pH}$ of textile effluents be neutralized to 7 . This trend of decolorization dependence on $\mathrm{pH}$ has been reported elsewhere [41, 42]. They found that $\mathrm{pH}$ between 7 and 9 was optimum for decolorization of triphenylmethane dyes by Pseudomonas otitidis WL-13. The effect of $\mathrm{pH}$ may be related to the transport of dye molecules across the cell membrane, which is considered a rate limiting step for dye decolorization [38]. At $\mathrm{pH}$ below $4, \mathrm{H}^{+}$ions compete effectively with dye cations, causing a decrease in color removal efficiency, while at higher $\mathrm{pH}$ above this point charge, the surface of biomass gets negatively charged, which attracts the positively charged dye cations through electrostatic force of attraction [15].

3.5. UV-Visible Spectral Analysis. UV-visible spectral analysis was used to confirm that the decolorization process of the triarylmethane dyes was due to biodegradation. If dye removal is attributed to biodegradation, either the major visible light absorbance peak would completely disappear

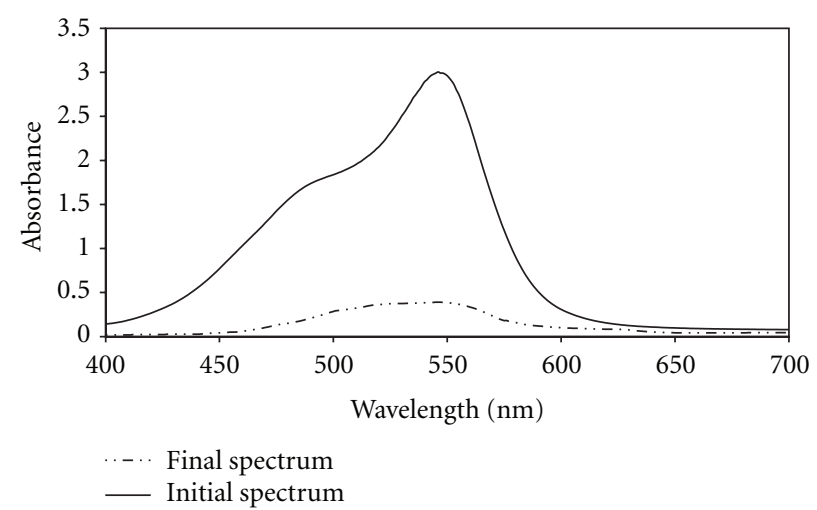

(a)

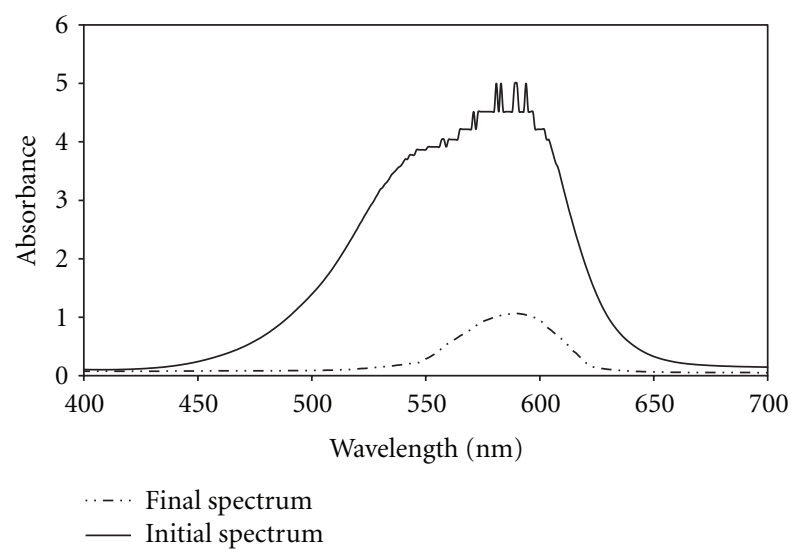

(b)

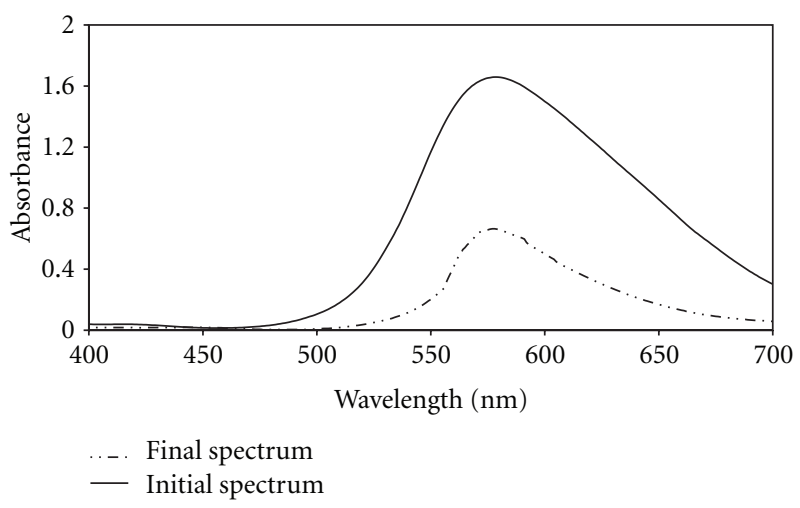

(c)

FIGURE 5: UV/visible spectra of triarylmethane dyes before and after degradation by Aeromonas hydrophila in synthetic wastewater medium (a) Basic violet 14, (b) Basic violet 3, and (c) Acid blue 90.

or a new peak will appear [33]. In adsorption examination, the absorption spectrum will reveal that all peaks decrease approximately in proportion to each other. Examination of spectral signatures of dyes indicated a decrease in the absorbance of samples withdrawn after decolorization using A. hydrophila (Figure 5). The absorbance peaks (at $0 \mathrm{~h}$ ) of the dyes drastically reduced albeit at different rates within $24 \mathrm{~h}$ of incubation. No new absorbance peak appeared in samples after scanning following decolorization which indicates 


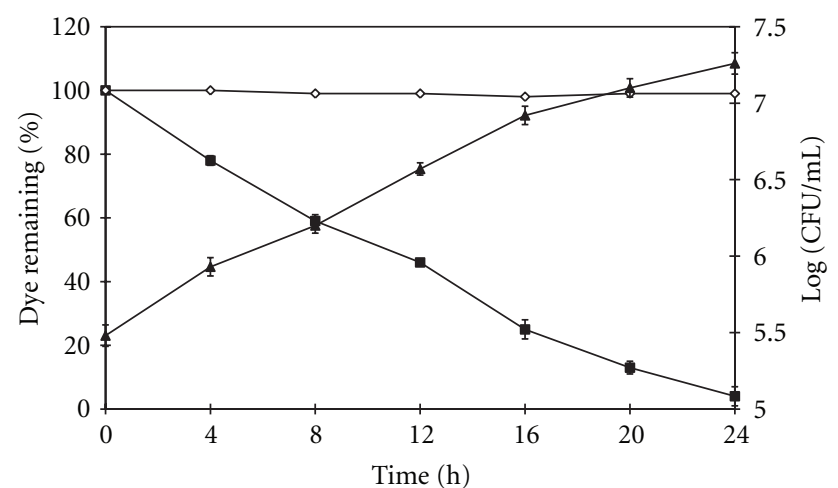

(a)

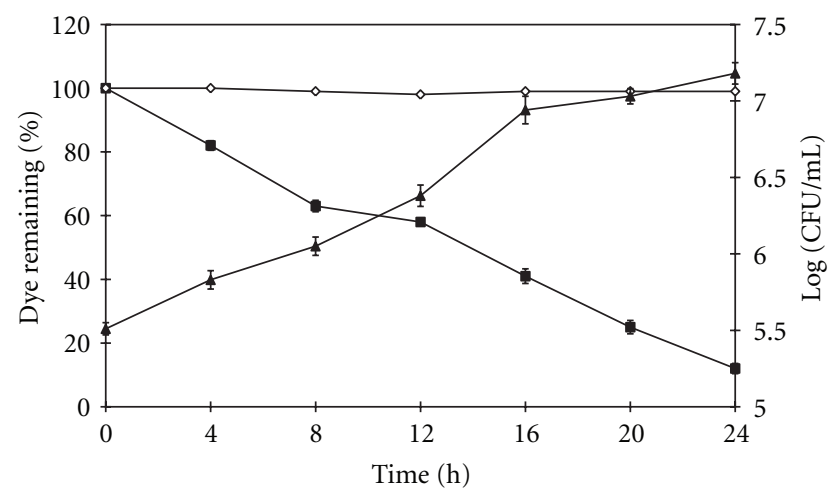

(b)

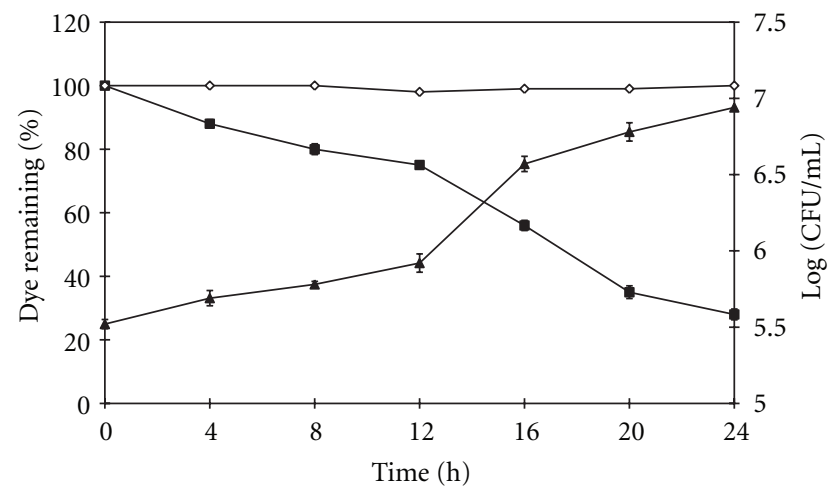

(c)

Figure 6: Time courses of growth and decolorization of triarylmethane dyes by Aeromonas hydrophila cultured in synthetic wastewater medium $(50 \mathrm{mg} / \mathrm{L}$ initial dye concentration; $\mathrm{pH} 7$; $35^{\circ} \mathrm{C}$ ) under agitated condition. (a) Basic violet 14 (b) Basic violet 3 (c) Acid blue 90. $(\diamond)$-Control (uninoculated medium with dye); ( $\square$ )-inoculated medium with dye; $(\boldsymbol{\Lambda})$ - Log cell number in culture. Data represent means $( \pm S D)$ of triplicate experiments.

the breakdown of the dyes to nonabsorbing metabolites. The time courses of growth and dye decolorization by A. hydrophila when cultured in SWM containing triarylmethane dyes are presented in Figure 6. Increase in cell number was obtained with a concomitant decrease in dye concentration suggesting the utilization of the dyes by the bacterial cells for growth. Results obtained generally reveal color removal by the test isolate was largely due to the biodegradation of the dyes rather than adsorption.

The optimal operational conditions for degradation of dyes by A. hydrophila were at $\mathrm{pH}$ 7-8 and incubation temperature of $35^{\circ} \mathrm{C}$. Effective decolorization was obtained in medium containing initial dye concentration of $50 \mathrm{mg} / \mathrm{L}$ or less. Similar results have been obtained as optimal conditions for degradation of azo and triphenylmethane dyes by other researchers $[37,41,43]$.

The effectiveness of dye decolorization was connected with dye chemical structure, molecular weight and the presence of functional groups. Higher \% decolorization was obtained with Basic violet 14 and Basic violet 3 which had lower molecular weights and simpler structures (Table 1). In the case of Acid blue 90, the relatively higher molecular weight (854.02), its complex structure and the presence of sulphonic groups may be responsible for its lower biodegradability. Dyes with sulphonic groups are usually highly polar compounds [44], and this makes it difficult for them to penetrate into the cells through the cell membrane. The influence of dye structure on decolorization effectiveness had been demonstrated in a previous report [41]. The bacterial strain tested (Citrobacter sp.), removed faster and more effectively structurally simpler Crystal violet and Methyl red than more complicated Gentian violet, Malachite green and Brilliant green. Similar dependence has been reported elsewhere [31, 45]. In our study, A. hydrophila showed some advantages during dye decolorization such as robust growth property and simple growth requirements, which make it a potential strain for biotreatment of textile industrial effluent. Moreover, A. hydrophila had previously been shown to produce polyhydroxyalkanoates (PHA) and poly3-hydroxybutyrate-co-3-hydroxyhexanoate) (PHBHHx) [4, $46,47]$. PHA and PHBHHx are biopolymers which are accumulated by microorganisms as carbon and energy reserves $[48,49]$. These biopolymers have material properties similar to petrochemical plastics such as enhanced flexibility and improved impact strength, and yet, they are biodegradable and can be produced from carbon sources. The ability of A. hydrophila to produce PHA and $\mathrm{PHBHHx}$ during dye degradation should be explored as this may offer more advantages in the use of $A$. hydrophila as a biotechnological agent for generation of useful bioproducts during treatment of wastewater.

3.6. Phytotoxicity Study. The disposal of untreated and treated textile dye wastewater on land may have a direct impact on soil fertility and by extension agricultural productivity. Thus, it was pertinent to assess the phytotoxicity of the dyes before and after degradation as environmental safety demands both pollutant removal and their detoxification. Phytotoxicity studies were carried out by evaluating the relative sensitivities of Triticum aestivum, Hordeum vulgare, and Lens esculenta toward the dyes and their degradation products using seed germination and plant growth assays. Germination (\%) of plant seeds was less with the raw dye treatment when compared to the treatment with degradation metabolites and SWM. The lengths of shoot, root, and 
TABLE 5: Toxic effect of treated and nontreated synthetic dye wastewater on Triticum aestivum.

\begin{tabular}{|c|c|c|c|c|c|c|c|}
\hline \multirow[b]{2}{*}{ Test parameters } & \multirow[b]{2}{*}{ Control } & \multicolumn{2}{|c|}{ Basic violet 14} & \multicolumn{2}{|c|}{ Basic violet 3} & \multicolumn{2}{|c|}{ Acid blue 90} \\
\hline & & $\begin{array}{l}\text { Untreated } \\
(50 \mathrm{mg} / \mathrm{L})\end{array}$ & $\begin{array}{c}\text { Treated } \\
(50 \mathrm{mg} / \mathrm{L})\end{array}$ & $\begin{array}{l}\text { Untreated } \\
(50 \mathrm{mg} / \mathrm{L})\end{array}$ & $\begin{array}{c}\text { Treated } \\
(50 \mathrm{mg} / \mathrm{L})\end{array}$ & $\begin{array}{l}\text { Untreated } \\
(50 \mathrm{mg} / \mathrm{L})\end{array}$ & $\begin{array}{c}\text { Treated } \\
(50 \mathrm{mg} / \mathrm{L})\end{array}$ \\
\hline Germination (\%) & $100^{\mathrm{a}}$ & $58^{\mathrm{b}}$ & $90^{\mathrm{a}}$ & $65^{\mathrm{b}}$ & $87^{\mathrm{a}}$ & $71^{\mathrm{b}}$ & $95^{\mathrm{a}}$ \\
\hline Shoot length $(\mathrm{cm})$ & $12.4 \pm 1.3^{\mathrm{a}}$ & $7.5 \pm 0.5^{\mathrm{b}}$ & $10.5 \pm 0.7^{\mathrm{a}}$ & $7.0 \pm 0.3^{b}$ & $11.1 \pm 0.5^{\mathrm{a}}$ & $8.3 \pm 0.3^{\mathrm{b}}$ & $11.4 \pm 0.4^{\mathrm{a}}$ \\
\hline Root length $(\mathrm{cm})$ & $10.8 \pm 0.8^{\mathrm{a}}$ & $6.1 \pm 0.2^{\mathrm{b}}$ & $9.2 \pm 0.5^{\mathrm{a}}$ & $5.8 \pm 1.1^{\mathrm{b}}$ & $9.6 \pm 0.3^{\mathrm{a}}$ & $7.9 \pm 0.7^{\mathrm{a}}$ & $9.5 \pm 0.8^{\mathrm{a}}$ \\
\hline Seedling length $(\mathrm{cm})$ & $23.3 \pm 1.2^{\mathrm{a}}$ & $13.8 \pm 0.6^{\mathrm{b}}$ & $19.9 \pm 0.8^{\mathrm{a}}$ & $12.6 \pm 0.9^{b}$ & $20.8 \pm 0.5^{\mathrm{a}}$ & $16.4 \pm 1.1^{\mathrm{b}}$ & $20.9 \pm 0.7^{\mathrm{a}}$ \\
\hline
\end{tabular}

Values are means of triplicate determinations, standard deviation $( \pm$ ), values followed by the same letter are not significantly different from the control (seeds germinated in SWM) at $P \leq 0.05$ according to the Dunett test.

TABLE 6: Toxic effect of treated and nontreated synthetic dye wastewater on Hordeum vulgare.

\begin{tabular}{|c|c|c|c|c|c|c|c|}
\hline \multirow[b]{2}{*}{ Test parameters } & \multirow[b]{2}{*}{ Control } & \multicolumn{2}{|c|}{ Basic violet 14} & \multicolumn{2}{|c|}{ Basic violet 3} & \multicolumn{2}{|c|}{ Acid blue 90} \\
\hline & & $\begin{array}{l}\text { Untreated } \\
(50 \mathrm{mg} / \mathrm{L})\end{array}$ & $\begin{array}{c}\text { Treated } \\
(50 \mathrm{mg} / \mathrm{L})\end{array}$ & $\begin{array}{l}\text { Untreated } \\
(50 \mathrm{mg} / \mathrm{L})\end{array}$ & $\begin{array}{c}\text { Treated } \\
(50 \mathrm{mg} / \mathrm{L})\end{array}$ & $\begin{array}{l}\text { Untreated } \\
(50 \mathrm{mg} / \mathrm{L})\end{array}$ & $\begin{array}{c}\text { Treated } \\
(50 \mathrm{mg} / \mathrm{L})\end{array}$ \\
\hline Germination (\%) & $100^{\mathrm{a}}$ & $60^{\mathrm{b}}$ & $95^{\mathrm{a}}$ & $63^{\mathrm{b}}$ & $90^{\mathrm{a}}$ & $70^{\mathrm{b}}$ & $100^{\mathrm{a}}$ \\
\hline Shoot length $(\mathrm{cm})$ & $13.8 \pm 0.4^{\mathrm{a}}$ & $6.7 \pm 0.5^{\mathrm{b}}$ & $10.8 \pm 1.1^{\mathrm{a}}$ & $7.4 \pm 0.4^{\mathrm{b}}$ & $11.5 \pm 0.5^{\mathrm{a}}$ & $7.9 \pm 0.4^{\mathrm{b}}$ & $13.2 \pm 0.4^{\mathrm{a}}$ \\
\hline Root length $(\mathrm{cm})$ & $8.0 \pm 0.3^{\mathrm{a}}$ & $3.5 \pm 0.2^{\mathrm{b}}$ & $7.3 \pm 0.7^{\mathrm{a}}$ & $4.1 \pm 0.6^{\mathrm{b}}$ & $7.5 \pm 0.7^{\mathrm{a}}$ & $3.7 \pm 0.6^{\mathrm{b}}$ & $8.2 \pm 0.8^{\mathrm{a}}$ \\
\hline Seedling length $(\mathrm{cm})$ & $22.2 \pm 0.5^{\mathrm{a}}$ & $10.8 \pm 0.6^{\mathrm{b}}$ & $18.2 \pm 0.4^{\mathrm{a}}$ & $11.6 \pm 0.4^{\mathrm{b}}$ & $18.8 \pm 0.8^{\mathrm{a}}$ & $11.6 \pm 1.2^{\mathrm{b}}$ & $21.4 \pm 0.8^{\mathrm{a}}$ \\
\hline
\end{tabular}

Values are means of triplicate determinations, standard deviation $( \pm)$, values followed by the same letter are not significantly different from the control (seeds germinated in SWM) at $P \leq 0.05$ according to the Dunett test.

TABLE 7: Toxic effect of treated and non treated synthetic dye wastewater on Lens esculenta.

\begin{tabular}{|c|c|c|c|c|c|c|c|}
\hline \multirow[b]{2}{*}{ Test parameters } & \multirow[b]{2}{*}{ Control } & \multicolumn{2}{|c|}{ Basic violet 14} & \multicolumn{2}{|c|}{ Basic violet 3} & \multicolumn{2}{|c|}{ Acid blue 90} \\
\hline & & $\begin{array}{l}\text { Untreated } \\
(50 \mathrm{mg} / \mathrm{L})\end{array}$ & $\begin{array}{c}\text { Treated } \\
(50 \mathrm{mg} / \mathrm{L})\end{array}$ & $\begin{array}{l}\text { Untreated } \\
(50 \mathrm{mg} / \mathrm{L})\end{array}$ & $\begin{array}{c}\text { Treated } \\
(50 \mathrm{mg} / \mathrm{L})\end{array}$ & $\begin{array}{l}\text { Untreated } \\
(50 \mathrm{mg} / \mathrm{L})\end{array}$ & $\begin{array}{c}\text { Treated } \\
(50 \mathrm{mg} / \mathrm{L})\end{array}$ \\
\hline Germination (\%) & $100^{\mathrm{a}}$ & $50^{\mathrm{b}}$ & $90^{\mathrm{a}}$ & $40^{\mathrm{b}}$ & $75^{\mathrm{b}}$ & $62^{b}$ & $95^{\mathrm{a}}$ \\
\hline Shoot length $(\mathrm{cm})$ & $13.6 \pm 0.5^{\mathrm{a}}$ & $5.6 \pm 0.7^{\mathrm{b}}$ & $10.7 \pm 0.7^{\mathrm{a}}$ & $7.5 \pm 0.3^{b}$ & $12.0 \pm 0.5^{\mathrm{a}}$ & $8.2 \pm 0.3^{\mathrm{b}}$ & $13.0 \pm 0.7^{\mathrm{a}}$ \\
\hline Root length (cm) & $11.2 \pm 0.2^{\mathrm{a}}$ & $5.7 \pm 0.3^{\mathrm{b}}$ & $9.5 \pm 0.6^{\mathrm{a}}$ & $6.5 \pm 0.7^{b}$ & $10.2 \pm 0.6^{\mathrm{a}}$ & $7.2 \pm 0.8^{\mathrm{b}}$ & $10.8 \pm 1.2^{\mathrm{a}}$ \\
\hline Seedling length $(\mathrm{cm})$ & $24.9 \pm 0.6^{\mathrm{a}}$ & $11.5 \pm 0.5^{\mathrm{b}}$ & $20.2 \pm 0.5^{\mathrm{a}}$ & $14.3 \pm 1.1^{\mathrm{b}}$ & $22.6 \pm 1.3^{\mathrm{a}}$ & $15.7 \pm 0.8^{\mathrm{b}}$ & $23.7 \pm 0.7^{\mathrm{a}}$ \\
\hline
\end{tabular}

Values are means of triplicate determinations, standard deviation $( \pm)$, values followed by the same letter are not significantly different from the control (seeds germinated in SWM) at $P \leq 0.05$ according to the Dunett test.

seedling were also significantly affected (Tables 5, 6 and 7) by the three dyes than by their degradation metabolites, indicating less toxic nature of degradation metabolites as compared to dyes. Amongst the dyes, treatment with Basic violet 14 showed the most toxic effect on seed germination and plant growth parameters whereas, treatment with Acid blue 90 exhibited the least toxic effect. However, for the dye metabolites, treatment with Basic violet 3 showed the most toxic effect while Acid blue 90 exhibited the least toxic effect. Results indicate that effective dye decolorization does not always result in reduction of dye toxicity since Basic violet 3 was better decolorized than Acid blue 90. However, toxicity exerted by the treated samples was generally lower than that obtained for the untreated samples. Before now, most of the decolorization projects have concentrated mainly on color removal while neglecting the fact that sometimes biological processes are connected with formation of toxic intermediates. Hence, it is required that the evaluation of decolorization effect be carried out with relation to ecotoxicity assessment. In this study, phytotoxicity studies have revealed that the biodegradation of triarylmethane dyes by $A$. hydrophila resulted in their detoxification and generation of nontoxic metabolites thus suggesting biotreated dye wastewater can be used for irrigation.

\section{Conclusions}

There are very few reports on the biodegradation and detoxification of textile and dye-stuff industrial wastes containing triarylmethane dyes. In this study, we describe the isolation and characterization of a strain of Aeromonas hydrophila capable of efficiently degrading triarylmethane dyes. The identity of the strain was confirmed using morphological, physiological, and biochemical assays. Degradation 
of dyes by the isolate was found to be dependent on dye concentration, aeration, $\mathrm{pH}$, as well as temperature and presence of a cosubstrate. Phytotoxicity tests carried out on three plant species also indicated detoxification of the dyes after degradation as decolorized samples exhibited lower toxic effects than the raw dyes. Effective dye wastewater treatment using this isolate will demand the optimization of medium components and physicochemical conditions for maximum decolorization and detoxification. The advantages of this biological process are low cost, rapid degradation, and simple handling and, hence, could be applied to treat wastewater from dyeing and printing operations and in bioremediation of dye contaminated environments. The next focus should be the design and scaling up of efficient tailor-made bioreactors with immobilized bacteria for the treatment of dye wastewater and to explore the potentials of producing useful biopolymer products from $A$. hydrophila during dye degradation.

\section{Acknowledgments}

The authors gratefully acknowledge the Coimbra Group, Europe, and the Aristotle University of Thessaloniki for funding this study in which C. J. Ogugbue worked as a Research Fellow.

\section{References}

[1] A. B. dos Santos, F. J. Cervantes, and J. B. van Lier, "Review paper on current technologies for decolourisation of textile wastewaters: perspectives for anaerobic biotechnology," Bioresource Technology, vol. 98, no. 12, pp. 2369-2385, 2007.

[2] T. Robinson, G. McMullan, R. Marchant, and P. Nigam, "Remediation of dyes in textile effluent: a critical review on current treatment technologies with a proposed alternative," Bioresource Technology, vol. 77, no. 3, pp. 247-255, 2001.

[3] H. Zollinger, "Synthesis, properties and applications of organic dyes and pigments," in Color Chemistry, VCH, New York, NY, USA, 1987.

[4] Y. Ji, X. T. Li, and G. Q. Chen, "Interactions between a poly(3-hydroxybutyrate-co-3-hydroxyvalerate-co-3-hydroxyhexanoate) terpolyester and human keratinocytes," Biomaterials, vol. 29, no. 28, pp. 3807-3814, 2008.

[5] S. R. Couto, "Dye removal by immobilised fungi," Biotechnology Advances, vol. 27, no. 3, pp. 227-235, 2009.

[6] C. O’Neill, F. R. Hawkes, D. L. Hawkes, N. D. Lourenço, H. M. Pinheiro, and W. Delée, "Colour in textile effluents - Sources, measurement, discharge consents and simulation: a review," Journal of Chemical Technology and Biotechnology, vol. 74, no. 11, pp. 1009-1018, 1999.

[7] C. M. Carliell, S. J. Barclay, C. Shaw, A. D. Wheatley, and C. A. Buckley, "The effect of salts used in textile dyeing on microbial decolourisation of a reactive azo dye," Environmental Technology, vol. 19, no. 11, pp. 1133-1137, 1998.

[8] P. Gregory, "Dyes and dyes intermediates," in Encyclopedia of Chemical Technology, J. I. Kroschwitz, Ed., vol. 8, pp. 544-545, John Wiley \& Sons, New York, NY, USA, 1993.

[9] V. K. Gupta, I. Ali, Suhas, and D. Mohan, "Equilibrium uptake and sorption dynamics for the removal of a basic dye (basic red) using low-cost adsorbents," Journal of Colloid and Interface Science, vol. 265, no. 2, pp. 257-264, 2003.

[10] I. M. Banat, P. Nigam, D. Singh, and R. Marchant, "Microbial decolorization of textile-dye-containing effluents: a review," Bioresource Technology, vol. 58, no. 3, pp. 217-227, 1996.

[11] R. Nilsson, R. Nordlinder, U. Wass, B. Meding, and L. Belin, "Asthma, rhinitis, and dermatitis in workers exposed to reactive dyes," British Journal of Industrial Medicine, vol. 50, no. 1, pp. 65-70, 1993.

[12] G. Parshetti, S. Kalme, G. Saratale, and S. Govindwar, "Biodegradation of malachite green by Kocuria rosea MTCC 1532," Acta Chimica Slovenica, vol. 53, no. 4, pp. 492-498, 2006.

[13] G. S. Ghodake, A. A. Talke, J. P. Jadhav, and S. P. Govindwar, "Potential of Brassica juncea in order to treat textile-effluentcontaminated sites," International Journal of Phytoremediation, vol. 11, no. 4, pp. 297-312, 2009.

[14] V. K. Gupta, A. Mittal, L. Krishnan, and V. Gajbe, "Adsorption kinetics and column operations for the removal and recovery of malachite green from wastewater using bottom ash," Separation and Purification Technology, vol. 40, no. 1, pp. 8796, 2004.

[15] N. Daneshvar, M. Ayazloo, A. R. Khataee, and M. Pourhassan, "Biological decolorization of dye solution containing Malachite Green by microalgae Cosmarium sp," Bioresource Technology, vol. 98, no. 6, pp. 1176-1182, 2007.

[16] H. Ali, W. Ahmad, and T. Haq, "Decolorization and degradation of malachite green by Aspergillus flavus and Alternaria solani," African Journal of Biotechnology, vol. 8, no. 8, pp. 15741576, 2009.

[17] W. Zhou and W. Zimmermann, "Decolorization of industrial effluents containing reactive dyes by actinomycetes," FEMS Microbiology Letters, vol. 107, no. 2-3, pp. 157-161, 1993.

[18] V. K. Gupta and A. Rastogi, "Biosorption of lead from aqueous solutions by green algae Spirogyra species: kinetics and equilibrium studies," Journal of Hazardous Materials, vol. 152, no. 1, pp. 407-414, 2008.

[19] V. K. Gupta and A. Rastogi, "Biosorption of hexavalent chromium by raw and acid-treated green alga Oedogonium hatei from aqueous solutions," Journal of Hazardous Materials, vol. 163, no. 1, pp. 396-402, 2009.

[20] S. W. Won, S. B. Choi, and Y. S. Yun, "Interaction between protonated waste biomass of Corynebacterium glutamicum and anionic dye Reactive Red 4," Colloids and Surfaces A, vol. 262, no. 1-3, pp. 175-180, 2005.

[21] K. Singh and S. Arora, "Removal of synthetic textile dyes from wastewaters: a critical review on present treatment technologies," Critical Reviews in Environmental Science and Technology, vol. 41, pp. 807-878, 2011.

[22] B. D. Tony, D. Goyal, and S. Khanna, "Decolorization of Direct Red 28 by mixed bacterial culture in an up-flow immobilized bioreactor," Journal of Industrial Microbiology and Biotechnology, vol. 36, no. 7, pp. 955-960, 2009.

[23] M. Gou, Y. Qu, J. Zhou, F. Ma, and L. Tan, "Azo dye decolorization by a new fungal isolate, Penicillium sp. QQ and fungal-bacterial cocultures," Journal of Hazardous Materials, vol. 170, no. 1, pp. 314-319, 2009.

[24] A. Telke, D. Kalyani, J. Jadhav, and S. Govindwar, "Kinetics and mechanism of reactive red 141 degradation by a bacterial isolate Rhizobium radiobacter MTCC 8161," Acta Chimica Slovenica, vol. 55, no. 2, pp. 320-329, 2008.

[25] C. Vanderzannt and D. F. Splittstoesser, Compendium of Methods for the Microbiological Examination of Foods, American 
public health association, Washington, DC, USA, 3rd edition, 1997.

[26] M. Cheesbrough, District Laboratory Practice in Tropical Countries, Part 2, Cambridge University Press, London, UK, 2000.

[27] J. G. Holt, N. R. Krieg, P. H. A. Sneath, J. T. Staley, and S. T. Williams, Bergey's Manual of Determinative Bacteriology, Lippincott Williams and Wilkins, Baltimore, Md, USA, 9th edition, 1994.

[28] E. Zablocka-Godlewska, W. Przystas, and E. Grabinska-Sota, "Decolourization of triphenylmethane dyes and ecotoxicity of their end products," Environmental Protection Engineering, vol. 35, no. 1, pp. 61-169, 2009.

[29] H. Wu, J. Pratley, D. Lemerle, M. An, and D. L. Liu, "Autotoxicity of wheat (Triticum aestivum $L$ ) as determined by laboratory bioassays," Plant and Soil, vol. 296, no. 1-2, pp. 8593, 2007.

[30] A. Fuentes, M. Llorens, M. J. Saez et al., "Ecotoxicity, phytotoxicity, and extractability of heavy metals from different stabilised sewage sludges," Environmental Pollution, vol. 1432, pp. 355-360, 2006.

[31] M. S. Jang, Y. M. Lee, C. H. Kim et al., "Triphenylmethane reductase from Citrobacter sp. strain KCTC 18061P: purification, characterization, gene cloning, and overexpression of a functional protein in Escherichia coli," Applied and Environmental Microbiology, vol. 71, no. 12, pp. 7955-7960, 2005.

[32] M. Tekere, A. Y. Mswaka, R. Zvauya, and J. S. Read, "Growth, dye degradation and ligninolytic activity studies on Zimbabwean white rot fungi," Enzyme and Microbial Technology, vol. 28, no. 4-5, pp. 420-426, 2001.

[33] K. C. Chen, J. Y. Wu, D. J. Liou, and S. C. J. Hwang, "Decolorization of the textile dyes by newly isolated bacterial strains," Journal of Biotechnology, vol. 101, no. 1, pp. 57-68, 2003.

[34] S. Z. Ren, J. Guo, Y. L. Wang, Y. H. Cen, and G. P. Sun, "Properties of a triphenylmethane dyes decolorization enzyme TpmD from Aeromonas hydrophila strain DN322," Acta Microbiologica Sinica, vol. 46, no. 3, pp. 385-389, 2006.

[35] S. Padamavathy, S. Sandhya, K. Swaminathan, Y. V. Subrahmanyam, and S. N. Kaul, "Comparison of decolorization of reactive azo dyes by microorganisms isolated from various sources," Journal of Environmental Sciences, vol. 15, no. 5, pp. 628-632, 2003.

[36] S. U. Jadhav, M. U. Jadhav, A. N. Kagalkar, and S. P. Govindwar, "Decolorization of brilliant blue G dye mediated by degradation of the microbial consortium of Galactomyces geotrichum and Bacillus sp," Journal of the Chinese Institute of Chemical Engineers, vol. 39, no. 6, pp. 563-570, 2008.

[37] R. G. Saratale, G. D. Saratale, J. S. Chang, and S. P. Govindwar, "Ecofriendly degradation of sulfonated diazo dye C.I. Reactive Green 19A using Micrococcus glutamicus NCIM2168," Bioresource Technology, vol. 100, no. 17, pp. 3897-3905, 2009.

[38] J. S. Chang and C. Y. Lin, "Decolorization kinetics of a recombinant Escherichia coli strain harboring azo-dye-decolorizing determinants from Rhodococcus sp," Biotechnology Letters, vol. 23, no. 8, pp. 631-636, 2001.

[39] Z. Aksu and G. Donmez, "A comparative study on the biosorption characteristics of some yeasts for Remazol Blue reactive dye," Chemosphere, vol. 50, no. 8, pp. 1075-1083, 2003.

[40] R. C. Wang, K. S. Fan, and J. S. Chang, "Removal of acid dye by $\mathrm{ZnFe} 2 \mathrm{O} 4 / \mathrm{TiO} 2$-immobilized granular activated carbon under visible light irradiation in a recycle liquid-solid fluidized bed," Journal of the Taiwan Institute of Chemical Engineers, vol. 40, no. 5, pp. 533-540, 2009.

[41] S. Y. An, S. K. Min, I. H. Cha et al., "Decolorization of triphenylmethane and azo dyes by Citrobacter sp," Biotechnology Letters, vol. 24, no. 12, pp. 1037-1040, 2002.

[42] J. Wu, B. G. Jung, K. S. Kim, Y. C. Lee, and N. C. Sung, "Isolation and characterization of Pseudomonas otitidis WL-13 and its capacity to decolorize triphenylmethane dyes," Journal of Environmental Sciences, vol. 21, no. 7, pp. 960-964, 2009.

[43] N. Junnarkar, D. S. Murty, N. S. Bhatt, and D. Madamwar, "Decolorization of diazo dye Direct Red 81 by a novel bacterial consortium," World Journal of Microbiology and Biotechnology, vol. 22, no. 2, pp. 163-168, 2006.

[44] M. A. Amoozegar, M. Hajighasemi, J. Hamedi, S. Asad, and A. Ventosa, "Azo dye decolorization by halophilic and halotolerant microorganisms," Annals of Microbiology, vol. 61, pp. 217-230, 2010.

[45] D. K. Sharma, H. S. Saini, M. Singh, S. S. Chimni, and B. S. Chadha, "Isolation and characterization of microorganisms capable of decolorizing various triphenylmethane dyes," Journal of Basic Microbiology, vol. 44, no. 1, pp. 59-65, 2004.

[46] G. Q. Chen, G. Zhang, S. J. Park, and S. Y. Lee, "Industrial scale production of poly(3-hydroxybutyrate-co-3-hy-droxyhexanoate)," Applied Microbiology and Biotechnology, vol. 57, no. 1-2, pp. 50-55, 2001.

[47] S. H. Lee, D. H. Oh, W. S. Ahn, Y. Lee, J. I. Choi, and S. Y. Lee, "Production of poly(3-hydroxybutyrate-co-3-hydroxyhexanoate) by high- cell-density cultivation of Aeromonas hydrophila," Biotechnology and Bioengineering, vol. 67, no. 2, pp. 240-244, 2000.

[48] B. Hazer and A. Steinbuchel, "Increased diversification of polyhydroxyalkanoates by modification reactions for industrial and medical applications," Applied Microbiology and Biotechnology, vol. 74, no. 1, pp. 1-12, 2007.

[49] A. Steinbuchel, "Perspectives for biotechnological production and utilization of biopolymers: metabolic engineering of polyhydroxyalkanoate Bbiosynthesis pathways as a successful example," Macromolecular Bioscience, vol. 1, no. 1, pp. 1-24, 2001. 

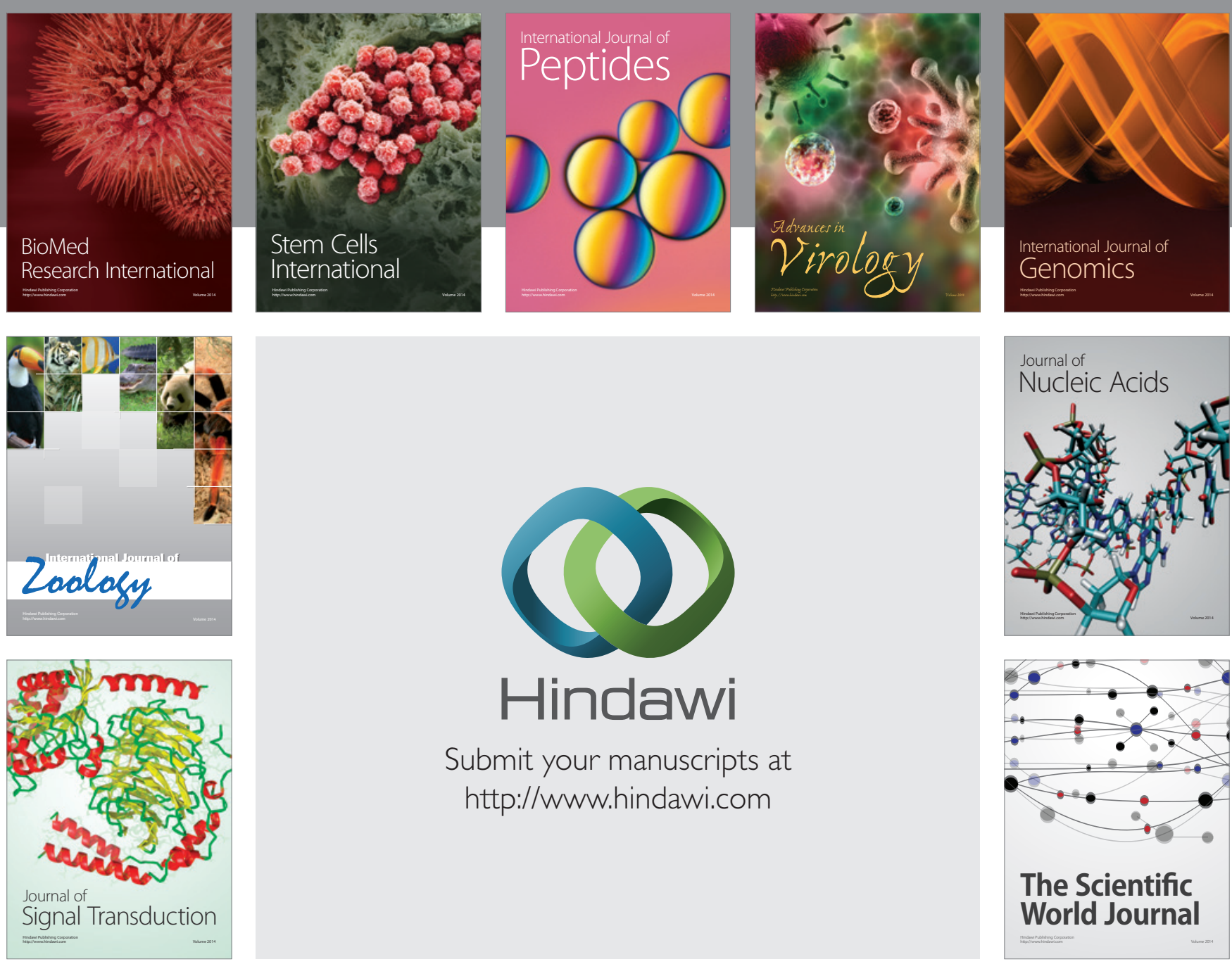

Submit your manuscripts at

http://www.hindawi.com
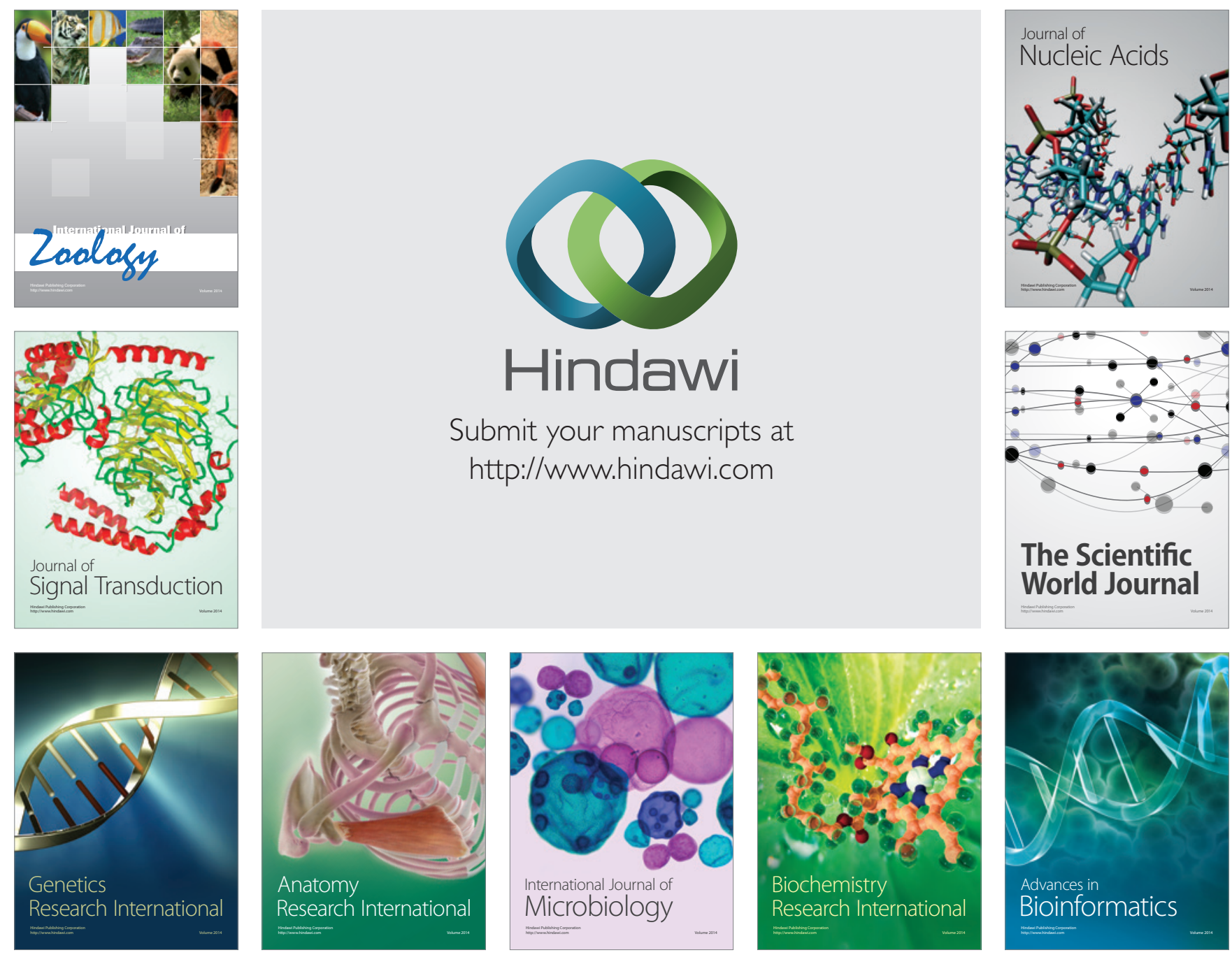

The Scientific World Journal
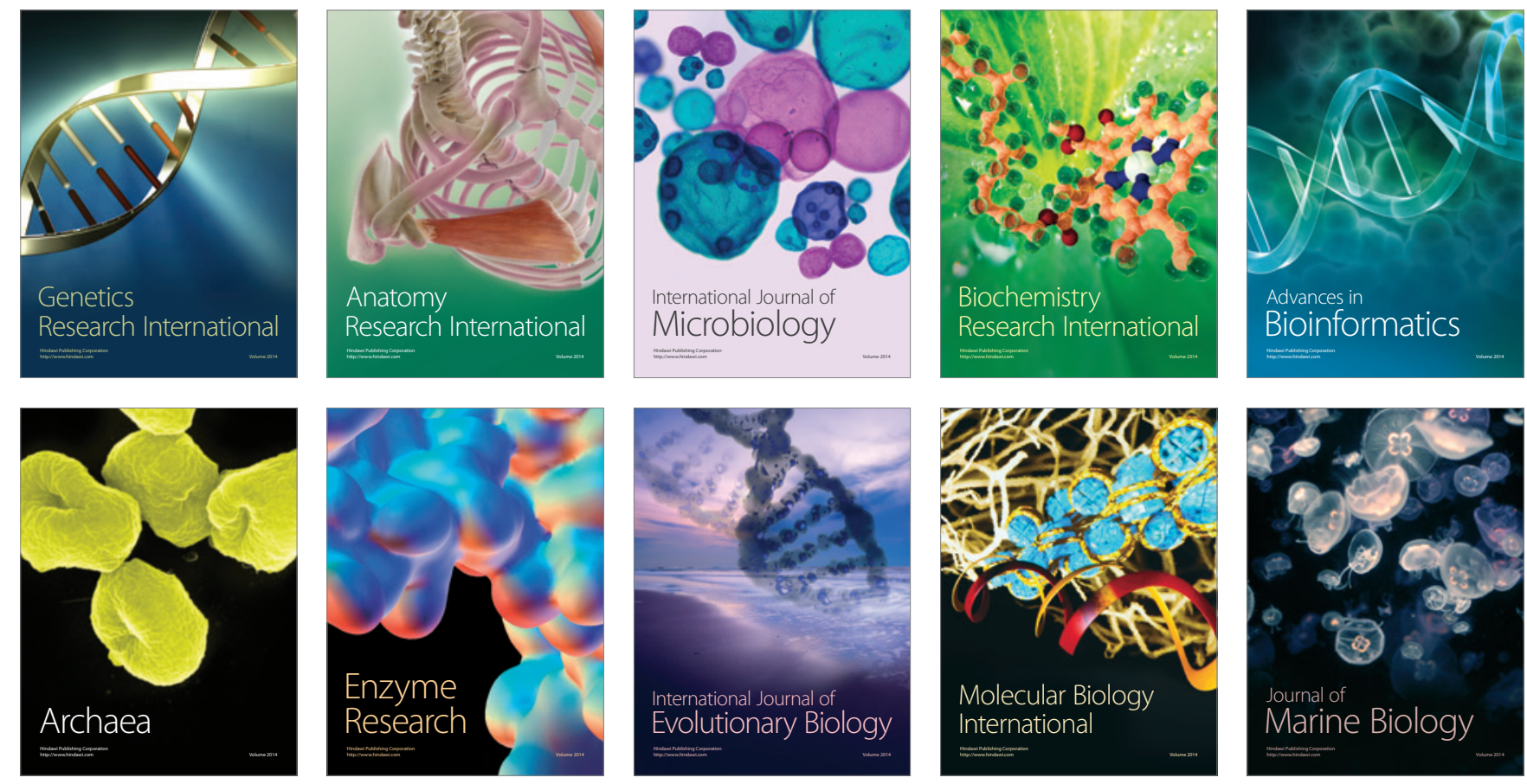